\title{
Clinicopathologic and genetic characteristics of gastric cancer in young male and female patients
}

\author{
SHOGO SASAO $^{1}$, TORU HIYAMA ${ }^{4}$, SHINJI TANAKA ${ }^{3}$, \\ MASAHARU YOSHIHARA ${ }^{4}$, WATARU YASUI ${ }^{2}$ and KAZUAKI CHAYAMA ${ }^{1}$
}

${ }^{1}$ Department of Medicine and Molecular Science; Division of Frontier Medical Science, ${ }^{2}$ Department of Molecular Pathology, Division of Molecular Medical Science, Programs for Biomedical Research, Graduate School of Biomedical Sciences, Hiroshima University; ${ }^{3}$ Department of Endoscopy, Hiroshima University Hospital, 1-2-3 Kasumi, Minami-ku, Hiroshima 734-8551; ${ }^{4}$ Health Service Center, Hiroshima University, 1-7-1 Kagamiyama, Higashihiroshima 739-8521, Japan

Received December 6, 2005; Accepted February 9, 2006

\begin{abstract}
The pathways of gastric cancer in young patients (40 years of age or younger) have not yet been determined. We therefore examined clinicopathologically and genetically 68 gastric cancers in young patients and 66 tumors in older patients (41 years of age or older). Mutations in B-raf and Kras were identified by PCR-SSCP following sequencing. Microsatellite instability (MSI) and $h M L H 3$ mutations were also examined. Histopathologically, diffuse-type gastric cancer and cancer in the whole of the stomach were found significantly more often in young patients than in older patients ( $21 \%$ vs. $2 \%, \mathrm{P}=0.0006$, and $77 \%$ vs. $32 \%, \mathrm{P}<0.0001$, respectively). Genetically, MSI and $h M L H 3$ mutations were found significantly more often in tumors in young patients than in tumors in older patients $(15 \%$ vs. $4 \%, \mathrm{P}=0.040$, and $9 \%$ vs. $0 \%, \mathrm{P}=0.036$, respectively). Tumors in young female patients were found significantly less often in the lower-third of the stomach and showed a significantly greater frequency of MSI, compared to tumors in young male patients (33\% vs. $9 \%, \mathrm{P}=0.046,5 \%$ vs. $30 \%, \mathrm{P}=0.010$, respectively). These results suggest that the pathways of gastric carcinogenesis differ between young patients and older patients, and that the pathways differ between the sexes in young patients.
\end{abstract}

\section{Introduction}

Gastric cancer has been decreasing in incidence over the last decade, but it is still the second most common cause of cancerrelated death worldwide (1). It occurs most frequently in

Correspondence to: Dr Shinji Tanaka, Department of Endoscopy, Hiroshima University Hospital, 1-2-3 Kasumi, Minami-ku, Hiroshima 734-8551, Japan

E-mail: colon@hiroshima-u.ac.jp

Key words: gastric cancer, microsatellite instability, $h M L H 3$, B-raf, $\mathrm{K}-$ ras individuals 50-70 years of age. Gastric cancer results from a combination of environmental factors and accumulation of specific genetic alterations. Environmental factors, such as Helicobacter pylori (H. pylori) infection and a high-salt diet, and genetic factors play important roles in gastric carcinogenesis $(2,3)$. Genetic alterations, such as activation of oncogenes K-ras and B-raf and inactivation of tumor suppressor gene $p 53$, play important roles in the development of gastric cancers (4). Dysfunction of DNA mismatch repair genes, which leads to microsatellite instability (MSI), also plays a crucial role (5).

Gastric cancers occurring in young patients (40 years of age or younger) account for less than $5 \%$ of all gastric cancers $(6,7)$. There have been several reports comparing clinicopathologic and biologic characteristics of young patients and older patients (more than 40 years of age) (8). Young patients with gastric cancer, in comparison to older patients, are thought to show a more aggressive clinical course and have a poorer prognosis. Thus, gastric cancers in young patients may have different genetic profiles from those in older patients. Although genetic characterization of gastric cancers has been the focus of several studies, few have addressed this issue specifically in young patients. The genetic pathways in young patients have not yet been determined. We therefore examined genetic alterations in gastric cancers to clarify differences in the disease between young patients and older patients.

\section{Materials and methods}

Study subjects were 134 patients with gastric cancer (68 young patients and 66 older patients) treated surgically at Hiroshima University Hospital or an affiliated hospital during the period 1990 through 2004. The young patients with gastric cancer were enrolled consecutively, and the older patients were enrolled randomly. For each patient, both cancerous and normal tissues were obtained at surgery.

Four-micrometer-thick sections were prepared from formalin-fixed, paraffin-embedded specimens. The sections were stained with hematoxylin and eosin $(\mathrm{H} \& \mathrm{E})$ for histologic examination. Gastric cancers were classified as intestinal- 
Table I. Primer sets used in the present study.

\begin{tabular}{|c|c|}
\hline Gene & Sequence \\
\hline K-ras & $\begin{array}{l}\text { sense: 5'-TTGTTGGATCATATTCGTCC-3' } \\
\text { antisense: 5'-TCAAAGAATGGTCCTGGACC-3' }\end{array}$ \\
\hline $\begin{array}{l}\text { B-raf } \\
\quad \text { exon } 11\end{array}$ & $\begin{array}{l}\text { sense: 5'-AAACACTTGGTAGACGGGAC-3' } \\
\text { antisense: 5'-ACTTGTCACAATGTCACCACATT-3' }\end{array}$ \\
\hline exon 15 & $\begin{array}{l}\text { sense: 5'-CTTCATGAAGACCTCACAGT-3' } \\
\text { antisense: 5'-GGCCAAAAATTTAATCAGTGGA-3' }\end{array}$ \\
\hline $\begin{array}{l}\text { hMLH3 } \\
\quad \text { codon 583-585 }\end{array}$ & $\begin{array}{l}\text { sense: 5'-GCCTTTTGCAACAACATTATGG-3' } \\
\text { antisense: 5'-GTGGAACATAATTTAACTCGCC-3' }\end{array}$ \\
\hline codon $672-674$ & $\begin{array}{l}\text { sense: 5'-AGACATCAAAGATTTAGCCAGC-3' } \\
\text { antisense: 5'-CTGTAGGTTCATTCTCTAGCC-3' }\end{array}$ \\
\hline BAT26 & $\begin{array}{l}\text { sense: 5'-TGACTACTTTTGACTTCAGCC-3' } \\
\text { antisense: 5'-AACCATTCAACATTTTTAACCC-3' }\end{array}$ \\
\hline
\end{tabular}

type or diffuse-type as defined by Lauren (9). Depth of invasion was classified as to the mucosa or submucosa (early stage) or to the muscularis propria or deeper (advanced stage). The presence of lymph node metastasis was also examined. To analyze the relationship between tumor location and genetic alterations, the stomach was divided into three parts: the upper, middle, and lower parts. H. pylori infection was examined histologically with Giemsa staining. The presence of follicular gastritis, a type of $H$. pylori-associated gastritis characterized by the presence of prominent lymphoid follicles in the mucosal layer of the stomach (10), was also examined in the patients.

Ten-micrometer-thick tissue sections were placed on glass slides and stained with H\&E. The tissue sections were then dehydrated in graded ethanol solutions and dried without a cover glass. Cancerous and normal tissues on the slides were scraped up with sterile needles, separately, by a microdissection technique. DNA was extracted from the tissues with $20 \mu \mathrm{l}$ of extraction buffer [100 mM of Tris- $\mathrm{HCl} ; 2 \mathrm{mM}$ of ethylene diamine tetraacetic acid (EDTA), $\mathrm{pH} 8.0 ; 400 \mu \mathrm{l} / \mathrm{ml}$ of proteinase $\mathrm{K}]$ at $55^{\circ} \mathrm{C}$ overnight. The tubes were boiled for $7 \mathrm{~min}$ to inactivate the proteinase $\mathrm{K}$, and then $2 \mu \mathrm{l}$ of the extracts was used for each polymerase chain reaction (PCR) amplification.

Each tumor was evaluated for MSI by analysis of the mononucleotide repeat, BAT26. The microsatellite assay was performed as described elsewhere (11). The primer sets used in the present study are shown in Table I. Briefly, each $15 \mu 1$ reaction mixture containing 10-20 ng of genomic DNA; $6.7 \mathrm{mM}$ of Tris- $\mathrm{HCl}$, (pH 8.8); $6.7 \mathrm{mM}$ of EDTA; $6.7 \mathrm{mM}$ of $\mathrm{MgCl}_{2}$; $0.33 \mu \mathrm{M}$ of primer labeled with $\left(\gamma^{-32} \mathrm{P}\right) \mathrm{dATP} ; 0.175 \mu \mathrm{M}$ of unlabeled primer; $1.5 \mathrm{mM}$ of each deoxynucleotide triphosphate; and 0.75 units of AmpliTaq Gold DNA polymerase (Perkin-Elmer, Branchburg, NJ) was amplified for 40 cycles as follows: denaturation at $94^{\circ} \mathrm{C}$ for $30 \mathrm{sec}$, annealing at $55^{\circ} \mathrm{C}$ for $30 \mathrm{sec}$, and strand elongation at $72^{\circ} \mathrm{C}$ for $30 \mathrm{sec}$. The PCR products were electrophoresed on $6 \%$ polyacrylamide- $8 \mathrm{M}$
Table II. Clinicopathologic characteristics of young and older patients with gastric cancer.

\begin{tabular}{lccc}
\hline Characteristics & $\begin{array}{c}\text { Young } \\
\text { patients }\end{array}$ & $\begin{array}{c}\text { Older } \\
\text { patients }\end{array}$ & P-value \\
\hline $\begin{array}{l}\text { Sex } \quad 39 / 29 \\
\quad \text { Male/female }\end{array}$ & $42 / 24$ & 0.46 \\
$\begin{array}{l}\text { Tumor location } \\
\quad \text { Whole stomach/other/NA }\end{array}$ & $11 / 42 / 15$ & $1 / 65 / 0$ & 0.0006 \\
$\begin{array}{l}\text { Histology } \\
\quad \text { Intestinal/diffuse }\end{array}$ & $16 / 52$ & $45 / 21$ & $<0.0001$ \\
$\begin{array}{l}\text { Tumor depth } \\
\quad \text { Early/advanced/NA }\end{array}$ & $25 / 40 / 3$ & $37 / 26 / 3$ & 0.022 \\
$\begin{array}{l}\text { Helicobacter pylori infection } \\
\quad \text { Positive/negative }\end{array}$ & $60 / 8$ & $66 / 0$ & 0.004 \\
$\begin{array}{l}\text { Follicular gastritis } \\
\quad \text { Present/absent }\end{array}$ & $4 / 64$ & $0 / 66$ & 0.063 \\
\hline
\end{tabular}

NA, information not available.

urea-32\% formamide gels and autoradiographed overnight at $-80^{\circ} \mathrm{C}$ with Fuji RX film. When additional bands appeared in the tumor DNA on the BAT26 marker, the tumor was defined as MSI-positive. Two mononucleotide repeats (poly A tracts) of $h M L H 3$ were also examined (12).

B-raf and K-ras genes were also examined. PCR-singlestrand conformation polymorphism (SSCP) analysis was performed as described previously (4). The aberrant migration band on the SSCP gel was removed, amplified again, and directly sequenced on both strands with an ABI PRISM 310 

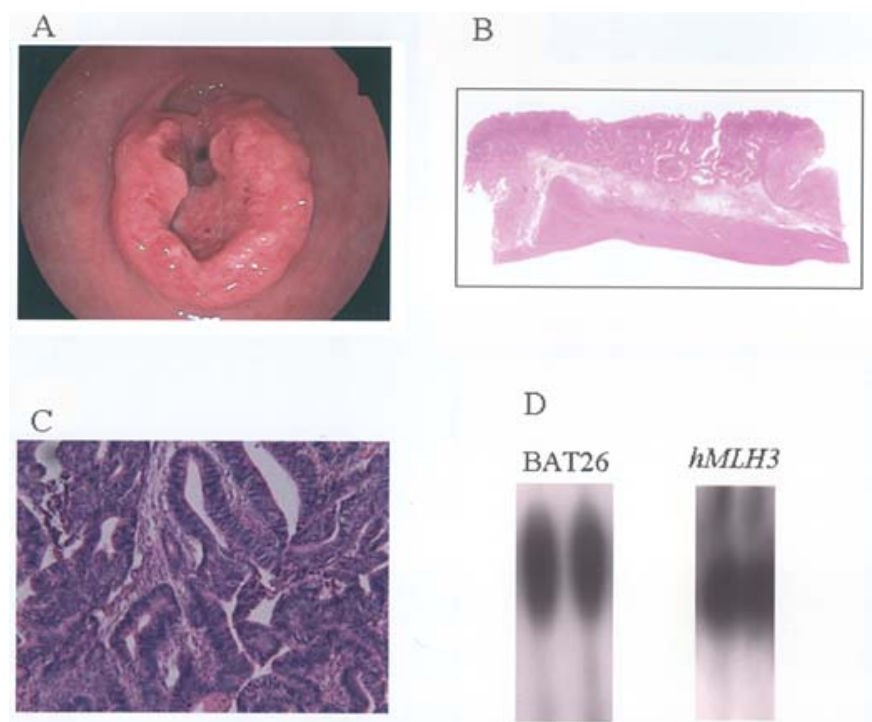

D

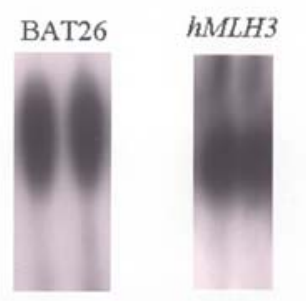

F

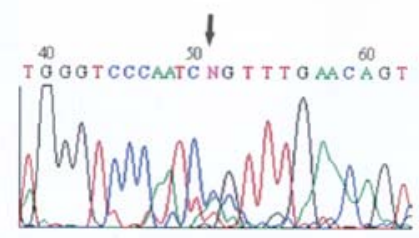

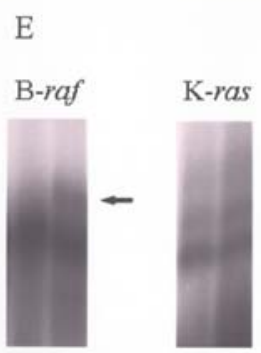

Figure 1. A representative case of intestinal-type gastric cancer. (A) Endoscopy revealed an ulcerated lesion at the greater curvature of the antral region. (B) Loupe appearance. (C) A histologically well-differentiated adenocarcinoma (x200) was identified. (D) Microsatellite analysis showed no alteration at BAT26 or $h M L H 3$. (E) PCR-SSCP analysis showed mobility shift of B-raf. (F) Sequencing analysis of B-raf showed a CAG to CCG mutation at codon 608 of exon 15 .

genetic analyzer (Perkin-Elmer ABI, Foster City, CA). For the sequencing reaction, a PRISM AmpliTaq DNA polymerase FS ready reaction dye terminator sequencing kit (PerkinElmer ABI) was used.

Fisher's exact probability and Chi-square tests were used for comparisons of clinicopathologic and genetic factors. $\mathrm{P}<0.05$ was regarded as significant.

\section{Results}

Representative cases are shown in Figs. 1 and 2. Clinicopathologic characteristics of young patients and older patients with gastric cancer are shown in Table II. The mean age of young gastric cancer patients was 35.3 (range, 18-40), and that of older gastric cancer patients was 64.5 (range, 44-90). Cancer in the whole of the stomach was found significantly more often in young patients than in older patients [11/53 (21\%) vs. $1 / 66(2 \%)$, respectively, $\mathrm{P}=0.0006$ by Fisher's exact probability test]. Histopathologically, diffuse-type gastric cancer was found significantly more often in young patients than in older patients [52/68 (77\%) vs. 21/66 (32\%), respectively, $\mathrm{P}<0.0001$ by Chi-square test]. Advanced tumors were significantly more prevalent in young patients than in older patients [40/65 (62\%) vs. 26/63 (41\%), respectively, $\mathrm{P}=0.022]$.
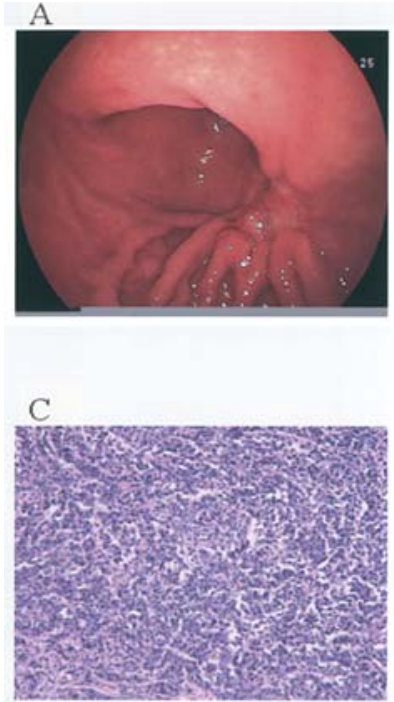

D

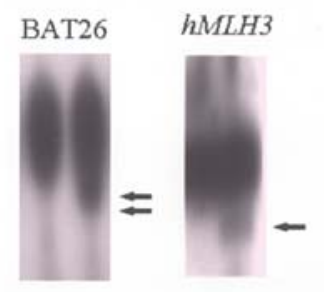

B

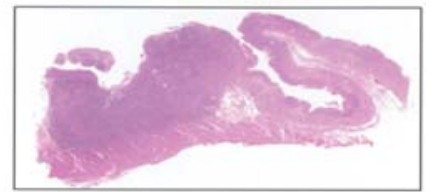

$\mathrm{E}$

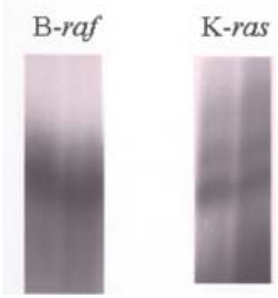

Figure 2. A representative case of diffuse-type gastric cancer. (A) Endoscopy revealed an ulcerated lesion at the posterior wall of the angular region. (B) Loupe appearance. (C) A histologically, diffuse, poorly differentiated adenocarcinoma (x200) was identified. (D) Microsatellite analysis showed alterations at BAT26 and $h M L H 3$. (E) PCR-SSCP analysis showed no mobility shift of B-raf and K-ras.

$H$. pylori infection was significantly less prevalent in young patients than in older patients [60/68 (88\%) vs. 66/66 (100\%), respectively, $\mathrm{P}=0.004]$. Follicular gastritis was observed more frequently in young patients than in older patients $[4 / 68(6 \%)$ vs. $0 / 66(0 \%)$, respectively, $\mathrm{P}=0.063$ by Fisher's exact probability test].

Genetic characteristics of gastric cancers in young patients and in older patients are shown in Table III. MSI was found significantly more often in tumors in young patients than in tumors in older patients $[10 / 65(15 \%)$ vs. $2 / 51(4 \%)$, respectively, $\mathrm{P}=0.040$ by Fisher's exact probability test]. Mutations in $h M L H 3$ were found significantly more often in tumors in young patients than in tumors in older patients [5/56 (9\%) vs. $0 / 51(0 \%)$, respectively, $\mathrm{P}=0.036$ by Fisher's exact probability test]. One detected K-ras mutation was a GGT to GCT (Gly to Ala) mutation at codon 12 . Out of $10 \mathrm{~B}$-raf mutations detected, 6 were CAT to CCG (His to Leu) mutations at codon 396 of exon 11, and 4 were CAG to CCG (Glu to Pro) mutations at codon 608 of exon 15. The frequencies of B-raf and K-ras mutations did not differ significantly between tumors in young patients and those in older patients.

The clinicopathologic characteristics of young gastric cancer patients are shown by sex in Table IV. There was a significant difference between the sexes in the number of tumors found in the lower-third of the stomach $[2 / 22$ females 
Table III. Genetic characteristics of gastric cancer in young and older patients.

\begin{tabular}{lccc}
\hline Genetic alteration & $\begin{array}{c}\text { Young } \\
\text { patients }\end{array}$ & $\begin{array}{c}\text { Older } \\
\text { patients }\end{array}$ & P-value \\
\hline $\begin{array}{l}\text { MSI } \\
\quad \text { +/-/NI }\end{array}$ & $10 / 55 / 3(15 \%)$ & $2 / 49 / 15(4 \%)$ & 0.040 \\
$\begin{array}{l}\text { hMLH3 mutation } \\
\quad \text { /-/NI }\end{array}$ & $5 / 51 / 12(9 \%)$ & $0 / 51 / 15(0 \%)$ & 0.036 \\
$\begin{array}{l}\text { B-raf mutation } \\
\quad \text { +/-/NI }\end{array}$ & $6 / 46 / 16(12 \%)$ & $4 / 46 / 16(8 \%)$ & 0.40 \\
$\begin{array}{l}\text { K-ras mutation } \\
\quad \text { +/-/NI }\end{array}$ & $0 / 23 / 45(0 \%)$ & $1 / 32 / 33(3 \%)$ & 0.59 \\
\hline
\end{tabular}

NI, not informative.

(9\%) vs. $10 / 31$ males (33\%), $\mathrm{P}=0.046$ by Fisher's exact probability test].

The genetic characteristics of gastric cancer in young patients are shown by sex in Table V. MSI was found significantly more often in female patients than in male patients [8/27 (30\%) vs. $2 / 38(5 \%)$, respectively, $\mathrm{P}=0.010$ by Fisher's exact probability test]. There were no significant differences in the frequencies of $h M L H 3, \mathrm{~B}-r a f$, and K-ras mutations between the sexes in young gastric cancer patients.

\section{Discussion}

Gastric cancers in young patients are reported to have different clinicopathologic characteristics from gastric cancers in older patients. For instance, diffuse-type gastric tumors and liver metastasis are reported to occur significantly more frequently in young patients than in older patients, and young patients are reported to have a more aggressive phenotype and poorer prognosis than older patients (8). These findings suggest that the pathways of gastric cancer in young patients differ from those in older patients. The increased frequency of cancer of the whole stomach and diffuse-type gastric cancer that we observed in young patients is similar to results reported previously. These data also suggest that the pathways of gastric cancer in young patients may differ from those in older patients.

We examined genetic alterations in gastric cancer to clarify whether the molecular profiles of tumors differ between young patients and older patients. Gastric cancer can occur as a hereditary non-polyposis colorectal cancer, whereby alterations in the mismatch repair genes ( $h M L H 1, h M S H 2, h M S H 6$, etc.) are responsible for colorectal, gastric, and endometrial tumor formation (13). Disrupted function of mismatch repair genes manifests as MSI and has been reported in 15-39\% of sporadic gastric cancer. A single test of BAT26 can identify cases positive for high-level MSI $(14,15)$. Several researchers have reported that MSI is rare (0-1.3\%) in gastric cancer in young patients. However, Hayden et al (6) reported MSI in $6 \%$ of gastric cancers in young patients, and Semba et al (16) reported
Table IV. Clinicopathologic characteristics of gastric cancer in young male and female patients.

\begin{tabular}{lccc}
\hline Characteristics & $\begin{array}{c}\text { Young } \\
\text { male } \\
\text { patients }\end{array}$ & $\begin{array}{c}\text { Young } \\
\text { female } \\
\text { patients }\end{array}$ & P-value \\
\hline $\begin{array}{l}\text { Tumor location } \\
\text { Lower third/others/NA }\end{array}$ & $10 / 21 / 8$ & $2 / 20 / 7$ & 0.046 \\
$\begin{array}{l}\text { Histology } \\
\text { Intestinal diffuse }\end{array}$ & $11 / 28$ & $5 / 24$ & 0.22 \\
$\begin{array}{l}\text { Tumor depth } \\
\text { Early/advanced/NA }\end{array}$ & $15 / 21 / 3$ & $10 / 19 / 0$ & 0.55 \\
$\begin{array}{l}\text { Helicobacter pylori infection } \\
\text { Positive/negative }\end{array}$ & $34 / 5$ & $26 / 3$ & 0.53 \\
$\begin{array}{l}\text { Follicular gastritis } \\
\text { Present/absent }\end{array}$ & $2 / 37$ & $2 / 27$ & 0.57 \\
\hline \begin{tabular}{l} 
NA, information not available. \\
\hline
\end{tabular} & & & \\
\hline
\end{tabular}

Table V. Genetic characteristics of gastric cancer in young male and female patients.

\begin{tabular}{llll}
\hline Genetic alteration & $\begin{array}{c}\text { Male } \\
\text { patients }\end{array}$ & $\begin{array}{l}\text { Female } \\
\text { patients }\end{array}$ & P-value
\end{tabular}

\section{MSI}

+/-/NI 2/36/1 $(5 \%) \quad 8 / 19 / 2(30 \%) \quad 0.010$

$\begin{array}{llll}\begin{array}{c}\text { hMLH3 mutation } \\ \text { +/-/NI }\end{array} & 2 / 30 / 7(6 \%) & 3 / 21 / 5(13 \%) & 0.36 \\ \begin{array}{c}\text { B-raf mutation } \\ \text { +/-/NI }\end{array} & 4 / 28 / 7(13 \%) & 2 / 18 / 9(10 \%) & 0.58\end{array}$

K-ras mutation
$+/-/ \mathrm{NI}$
$0 / 13 / 26(0 \%)$
$0 / 10 / 19(0 \%)$

NI, not informative.

MSI in $22 \%$ of gastric cancers in young patients. In the present study, $15 \%$ of gastric cancers in young patients showed MSI, and MSI was found significantly more often in tumors in young patients than in tumors in older patients. In addition, tumors in young patients had significantly frequent mutations of $h M L H 3$, one of the mismatch repair genes, compared with tumors in older patients. Mutation of the major mismatch repair genes, $h M S H 2$ and $h M L H 1$, has not been detected in gastric cancers in young patients (17). Thus, it is possible that $h M L H 3$ mutation is a key genetic change in the development of gastric cancer in young patients. The number of cases examined in the present study was limited; further examination of genetic changes in a greater number of cases may be necessary. 
We previously reported that follicular gastritis confers a high-risk for diffuse-type gastric cancer and is predominant in female patients $(10,18)$. In the present study, cancer in the whole of the stomach and MSI were was found significantly more often in young females than in young males, and follicular gastritis tended to be more common in young females than in young males. These results suggest differences between the sexes in the genetic pathways of gastric cancer in young patients. This is the first reported study to focus on differences between the sexes regarding the clinicopathologic and genetic characteristics of gastric cancer in young patients.

ras genes are the most frequently mutated oncogenes in human cancers (19). The vast majority of ras mutations associated with human diseases involve K-ras (20). Activating point mutations of the gene affect codons 12 and 13. K-ras mutations are reported in $2.8-20 \%$ of gastric cancers (4). In the present study, K-ras mutations were detected in only $3 \%$ of tumors in older patients and in none of the tumors in young patients. The results were similar to those reported previously.

Recently, B-raf mutations have been reported in human malignancies, such as colon cancer and melanoma (21). Almost all reported B-raf mutations have occurred within two kinase domains (the G-loop domain and kinase domain), and the most common mutation is a single substitution, V599E. B-raf protein plays a central role in the ras/raf/mek/erk pathway, relaying signals from activated RAS proteins. B-raf mutations in gastric cancer are reportedly infrequent at $0-2.2 \%(22,23)$. In the present study, B-raf mutations were detected in $12 \%$ of tumors in young patients and in $8 \%$ of tumors in older patients. The percentages in the present study were high compared to those reported previously. However, there was no significant difference in the frequency of B-raf mutations between young patients and older patients.

The B-raf and K-ras mutations were infrequent, and there were no significant differences in the frequencies of these gene mutations between the sexes. These genes may not be key genetic alterations in the development of gastric cancers.

In conclusion, the clinicopathologic and genetic differences in gastric cancer that we observed between young patients and older patients suggest that the pathways of gastric cancer development differ between these two groups. In addition, the clinicopathologic and genetic differences that we observed between gastric cancer in young male patients and that in young female patients suggest different pathways. Thus, even among young patients, the pathways of gastric cancer development may differ, depending on sex.

\section{References}

1. Parkin DM, Pisani P and Ferlay J: Estimates of the worldwide incidence of eighteen major cancers in 1985. Int J Cancer 54: 594-606, 1993.

2. Meyers WC, Damiano RJ Jr, Rotolo FS and Postlethwait RW: Adenocarcinoma of the stomach. Changing patterns over the last 4 decades. Ann Surg 205: 1-8, 1987.

3. Miyoshi E, Haruma K, Hiyama T, Tanaka S, Yoshihara M, Shimamoto F and Chayama K: Microsatellite instability is a genetic marker for the development of multiple gastric cancers. Int J Cancer 95: 350-353, 2001.

4. Hiyama T, Haruma K, Kitadai Y, Masuda H, Miyamoto M, Tanaka S, Yoshihara M, Shimamoto F and Chayama K: K-ras mutation in Helicobacter pylori-associated chronic gastritis in patients with and without gastric cancer. Int J Cancer 97: 562-566, 2002.
5. Hiyama T, Tanaka S, Yoshihara M, Sasao S, Kose K, Shima H, Tuncel H, Ueno Y, Ito M, Kitadai Y, Yasui W, Haruma K and Chayama K: Chromosomal and microsatellite instability in sporadic gastric cancer. J Gastroenterol Hepatol 19: 756-760, 2004.

6. Hayden JD, Cawkwell L, Sue-Ling H, Johnston D, Dixon MF, Quirke P and Martin IG: Assessment of microsatellite alterations in young patients with gastric adenocarcinoma. Cancer 79: 684-687, 1997.

7. Mori M, Sugimachi K, Ohiwa T, Okamura T, Tamura S and Inokuchi K: Early gastric carcinoma in Japanese patients under 30 years of age. Br J Surg 72: 289-291, 1985.

8. Nakamura T, Yao T, Niho Y and Tsuneyoshi M: A clinicopathological study in young patients with gastric carcinoma. J Surg Oncol 71: 214-219, 1999.

9. Lauren P: The two histological main types of gastric carcinoma: Diffuse and so-called intestinal-type carcinoma. An attempt at a histo-clinical classification. APMIS 64: 31-49, 1965.

10. Miyamoto M, Haruma K, Hiyama T, Kamada T, Masuda H, Shimamoto F, Inoue K and Chayama K: High incidence of Bcell monoclonality in follicular gastritis: a possible association between follicular gastritis and MALT lymphoma. Virchows Arch 440: 376-380, 2002

11. Hiyama T, Tanaka S, Kitadai Y, Ito M, Sumii M, Yoshihara M, Shimamoto F, Haruma K and Chayama K: p53 codon 72 polymorphism in gastric cancer susceptibility in patients with Helicobacter pylori-associated chronic gastritis. Int J Cancer 100: 304-308, 2002.

12. Akiyama Y, Nagasaki H, Nakajima T, Sakai H, Nomizu T and Yuasa Y: Infrequent frameshift mutations in the simple repeat sequences of $h M L H 3$ in hereditary nonpolyposis colorectal cancers. Jpn J Clin Oncol 31: 61-64, 2001.

13. Wu M, Semba S, Oue N, Ikehara N, Yasui W and Yokozaki H: BRAF/K-ras mutation, microsatellite instability, and promoter hypermethylation of hMLH1/MGMT in human gastric carcinomas. Gastric Cancer 7: 246-253, 2004.

14. Boland CR, Thibodeau SN, Hamilton SR, Sidransky D, Eshleman JR, Burt RW, Meltzer SJ, Rodriguez-Bigas MA, Fodde R, Ranzani GN and Srivastava S: A National Cancer Institute Workshop on Microsatellite Instability for cancer detection and familial predisposition: development of international criteria for the determination of microsatellite instability in colorectal cancer. Cancer Res 58: 5248-5257, 1998.

15. Hoang JM, Cottu PH, Thuille B, Salmon RJ, Thomas G and Hamelin R: BAT-26, an indicator of the replication error phenotype in colorectal cancers and cell lines. Cancer Res 57: 300-303, 1997.

16. Semba S, Yokozaki H, Yasui W and Tahara E: Frequent microsatellite instability and loss of heterozygosity in the region including BRCA1 (17q21) in young patients with gastric cancer. Int J Oncol 12: 1245-1251, 1998.

17. Lim S, Lee HS, Kim HS, Kim YI and Kim WH: Alteration of Ecadherin-mediated adhesion protein is common, but microsatellite instability is uncommon in young age gastric cancers. Histopathology 42: 128-136, 2003.

18. Miyamoto M, Haruma K, Yoshihara M, Sumioka M, Nishisaka T, Tanaka S, Inoue $\mathrm{K}$ and Chayama K: Five cases of nodular gastritis and gastric cancer : a possible association between nodular gastritis and gastric cancer. Dig Liver Dis 34: 819-820, 2002.

19. Kiaris H and Spandidos DA: Mutations of ras genes in human tumours (Review). Int J Oncol 7: 413-421, 1995.

20. Ellis CA and Clark G: The importance of being K-Ras. Cell Signal 12: 425-434, 2000.

21. Davies H, Bignell GR, Cox C, Stephens P, Edkins S, Clegg S, Teague J, Woffendin H, Garnett MJ, Bottomley W, Davis N, Dicks E, Ewing R, Floyd Y, Gray K, Hall S, Hawes R, Hughes J, Kosmidou V, Menzies A, Mould C, Parker A, Stevens C, Watt S, Hooper S, Wilson R, Jayatilake H, Gusterson BA, Cooper C, Shipley J, Hargrave D, Pritchard-Jones K, Maitland N, Chenevix-Trench G, Riggins GJ, Bigner DD, Palmieri G, Cossu A, Flanagan A, Nicholson A, Ho JW, Leung SY, Yuen ST, Weber BL, Seigler HF, Darrow TL, Paterson H, Marais R, Marshall CJ, Wooster R, Stratton MR and Futreal PA: Mutations of the BRAF gene in human cancer. Nature 417: 949-954, 2002.

22. Lee SH, Lee JW, Soung YH, Kim HS, Park WS, Kim SY, Lee JH, Park JY, Cho YG, Kim CJ, Nam SW, Kim SH, Lee JY and Yoo NJ: BRAF and KRAS mutations in stomach cancer. Oncogene 22: 6942-6945, 2003

23. Oliveira C, Pinto M, Duval A, Brennetot C, Domingo E, Espin E, Armengol M, Hamelin R, Seruca R and Schwartz S Jr: BRAF mutations characterize colon but not gastric cancer with mismatch repair deficiency. Oncogene 22: 9192-9196, 2003. 